\title{
DELIVERY BEHAVIOR OF CAFFEINE CONTROLLED RELEASE DOSAGE FORM ON HYDROPHILIC MATRICES
}

\author{
Avaliação do comportamento da distribuição de doses \\ controladas de cafeína em matrizes hidrofílicas
}

\author{
Antonio Teixeira ${ }^{1}$ \\ Sammy Ibrahim ${ }^{2}$ \\ Frank Martinuzzi ${ }^{3}$
}

\begin{abstract}
The aim of this experiment was to evaluate the release behavior of caffeine as once daily drug on hydrophilic matrices. Caffeine was selected as a model drug because of its short half live and rapid absorption. To decrease the rate of drug release to the absorption site, the physical barrier was prepared by compressing a mixture of a hydrophilic polymer and drug. The hydrophilic polymers used in this experiment were hydroxypropylcellulose (HPC) and corn starch. It was found that the increase of HPC level on the formulation contributed significant changes on the drug release. The study also investigated the influences of diluents (corn starch:lactose) on the HPC matrix. The results showed that the presence of starch on the matrix tablet could modify the release rate. The mechanism of release was found to be anomalous. This is mainly due to the fact that all of $\mathrm{n}$ values from the release kinetics varied from 0.7317 to 0.8575 with squared correlation coefficient in the range of $0.9904-0.9967$.
\end{abstract}

Keywords: Hydroxypropylcellulose; Controlled release; Corn starch; Lactose; Hydrophilic.

\section{Resumo}

O propósito deste trabalho foi avaliar o comportamento na liberação da cafeína como uma droga diária em matrizes hidrofílicas. A cafeína foi escolhida como modelo de droga por causa de seu curto período de meia-vida e rápida absorção. Para diminuir a velocidade de liberação da droga no sítio de absorção, a barreira física foi preparada por meio da compressão de um polímero hidrofílico e a droga. Os polímeros hidrofílicos usados neste experimento foram hidroxipropilcelulose (HPC) e amido de milho. Foi observado que o aumento dos níveis de HPC na formulação contribuiu significantemente na mudança da liberação da droga. O estudo também investigou as influências de diluentes (amido de milho: lactose) sobre a matriz de HPC. Os resultados mostraram que a presença de amido sobre a matriz do comprimido poderia modificar a velocidade de liberação. O mecanismo de liberação foi considerado anômalo, devido ao fato de que todos os valores $\mathrm{n}$ da cinética de liberação variaram de 0,7317 a 0,8575 com o quadrado do coeficiente de correlação na faixa de 0,9904-0,9967.

Palavras-chave: Hidroxiproprilcelulose; Liberação controlada; Amido de milho; Lactose; Hidrofílico.

\footnotetext{
Chemistry Department - Federal University of Mato Grosso - UFMT, azteixei@ufmt.br, Cuiaba - MT, Brazil.

Graduated Student at Toronto Institute of Pharmaceutical Technology, Toronto - ON, Canada.

Toronto Institute of Pharmaceutical Technology, Toronto - ON, Canada.
} 


\section{Introduction}

The principle goal of controlled release dosage form (CRDF) is to improve therapy (1, 2) that maintain therapeutic blood or tissue levels of the drug for an extended period, thus, the drug must enter the circulation at approximately the same rate at which it is eliminated. Drug with short half lives are excellent candidate for CRDF, since this can reduce dosing frequency $(3,4)$. The majority of prolonged action dosage forms use physical barrier to decrease the rate of drug release to the absorption site. One type of prolonged action tablet can be prepared by compressing a mixture of a hydrophilic polymer and drug (5). Among hydrophilic polymers, polysaccharides are the choice material due to their non toxicity and acceptance by regulating authorities $(6,7)$. One of polysaccharides like cellulose ether is hydroxypropylcellulose (HPC). It acts as a disintegrant (8) and as a binder in granulation (9). Since the use of polymers and other materials to prolong the drug release has become more popular, the use of polymers combinations is an approach that may allow formulators to develop sustained release drug dosage forms that may show performance improvements over the individual polymer components. Natural polysaccharide, starch is one of the most abundant biopolymers in nature (10). Starch granules are composed of two polysaccharides polymers: largely linear amylose and highly branched amylopectin (11). Native starches are particularly useful excipients as a result of their good binding and disintegrant properties (12). This study examined the release behavior of caffeine as once daily drug on hydrophilic matrices. Caffeine was selected as a model drug due to its short half live, 3-5 hours (13) and 2.5-4.5 (14). Moreover, caffeine's absorption from the gastrointestinal tract is rapid and reaches almost 99\% in humans in about 45 minutes after ingestion (15). The combination of corn starch, lactose and microcrystalline cellulose applied as diluents on hydroxypropylcellulose (HPC) matrix tablets.

\section{Material and methods}

\section{Materials}

All materials were complied with current USP/NF compendial specifications and all were obtained from Toronto Institute Pharmaceutical Technology (TIPT), ON, Canada. Anhydrous Caffeine, water-soluble drug (lot \# 03A0808) was used as active ingredient. Hydroxypropylcellulose (HPC, lot \# S-1101), corn starch (lot \# T97B307), carboxymethylcellulose (CMC, lot \# 04B0910), polyvinylpyrrolidone (PVP K90, lot \# T99B0311) and lactose monohydrate (lot \# 04B0204) were used as excipients.

\section{Methods}

\section{Tablets preparation}

Different tablets formulations (Table 1) were mixed and blended. Powder characteristics were previously determined. The flow ability of all powders was measured by Carr's index and angle of repose. Particle size and its distribution were analyzed using a shaker machine, ROTAP model RX 29 serial\#11488TIPT97001. The procedures for the sieve analysis followed the USP Physical Tests $<786>$ on solid particles. The moisture content of the excipients was determined gravimetrically on Sartorius Moisture Balance TIPT \# LOD 002. From particle size measurement, it was found that caffeine has large particle size distribution, which relates to segregation issue. In addition, from flowability test, the results were obtained show that caffeine, lactose and PVP have poor flow. To avoid the problems associated with compressibility and segregation during the manufacturing processes (16), the method of wet granulation was selected. Then, the granules were lubricated with $1 \%$ of magnesium stearate and compressed on tablet compression machine (Penwalt Stokes). The range of the pressure $(1 \mathrm{kN}$ to $25 \mathrm{kN})$ was used to compress the tablets. For each compact was weighed on analytical balance ID \# EB003. The yield of the granules was assumed 100\% since the compression was done manually and the tool size was $21 \mathrm{x} 12 \mathrm{~mm}$. 
TABLE 1 - Formulations of caffeine on hydrophilic matrix. The caffeine loading of 582 mg was kept constant in the tablets of these batches. The additional 1\% of magnesium stearate as lubricant for $B 1-B 4$ and $0.5 \%$ of magnesium stearate for $B 5-B 8$

Batch Caffeine HPC HXF CMC PVP K90 Diluent

Lactose:Starch:MCC

\begin{tabular}{cccccc}
\hline & \multicolumn{5}{c}{$\boldsymbol{( \% \text { of } \text { tablet weight } )}$} \\
\hline B-1 & 44.77 & 40.29 & 8.95 & 5.00 & - \\
B-2 & 47.99 & 43.19 & 2.40 & 5.36 & - \\
B-3 & 61.21 & 18.36 & 12.24 & 6.84 & - \\
B-4 & 67.40 & 20.22 & 3.37 & 7.53 & - \\
B-5 & 40 & 30 & 5 & 2.5 & $8.5: 8.5: 5$ \\
B-6 & 72 & 10 & 5 & 2.5 & $3.9: 3.9: 2.2$ \\
B-7 & 52 & 30 & 5 & 2.5 & $3.9: 3.9: 2.2$ \\
B-8 & 60 & 10 & 5 & 2.5 & $8.5: 8.5: 5$ \\
\hline
\end{tabular}

\section{Swelling study}

The swelling study was performed in 900 $\mathrm{ml}$ distilled water and phosphate buffer at $\mathrm{pH} 6.8$ on dissolution test apparatus. Water temperature was maintained at $21-26^{\circ} \mathrm{C}$. The swollen hydrogel was momentarily removed from the media at certain interval time $(1,2,3,5,7,9,12,15,18,21,24$ hours) and filtered to remove any surface moisture before weighing using a density determination kit, Mettler Toledo.

\section{Dissolution studies}

The release rate from each batch was carried out in vitro using dissolution test apparatus Vankel ID\#DSL008. The samples were immersed in $900 \mathrm{ml}$ distilled water and phosphate buffer at $\mathrm{pH}$ 6.8. The temperature was maintained at $37^{\circ}$ $\pm 0.5^{\circ} \mathrm{C}$ at paddle rotation speed $75 \mathrm{rpm}$ (USP Apparatus 2). A sample of dissolution was withdrawn from each of 6 vessels and analyzed for caffeine by UV absorbance at $274 \mathrm{~nm}$ using UV-Visible detector. The samples were measured at the point of $1,2,3,5,7,9,12,15,18,21,24$ hours and accelerated at the end for 1 hour at 200 rpm. The average values of drug release were calculated for data analysis.

\section{Release kinetics}

Analysis of drug release from swellable matrices was performed with a flexible exponential model (17) that can identify the different contribution to overall kinetics. The model is written as:

\section{$\mathrm{Mt} / \mathrm{M} \infty=\mathrm{kt}^{\mathrm{n}}$}

where

Mt $/ \mathrm{M}^{\infty}=\mathrm{a}$ fractional drug release at time $\mathrm{t}, \mathrm{k}=\mathrm{a}$ constant incorporating the properties of the macromolecular polymeric systems and the drugs, $n=a$ kinetic constant which depends on and is used to characterize the transport mechanism. The value of $\mathrm{n}$ for a tablet, $\mathrm{n}=0.45$ for Fickian (Case I), $0.45<\mathrm{n}>0.89$ for anomalous release, and $n=0.89$ for case II (relaxation) transport. 


\section{Results and discussion}

Hydrophilic matrices containing sweallable polymers are also referred to as hydrogel matrices. Hydrogels are three-dimensional, hydrophilic, polymeric network that is able to absorb large amounts of water (18). These hydrogels exhibit a thermodynamic compatibility with water which allows them to swell in aqueous media $(19,20)$. On swelling, drug molecules dissolve in water and are released by diffusion. Since the diffusional release of a soluble drug may primarily be controlled by the gel thickness, increasing polymer level tends to decrease the drug release (Fig. 1). The highest release rate at 24 hours was obtained by B- 4 at 66.61\% which contained the lowest polymers blending, then, followed by B-3 (56.59\%), B-2 (48.14\%) and B-1 at $44.58 \%$. Given the complexity of these swellable matrix systems, other factors such as differences in water penetration rate, water absorption capacity and swelling, polymer erosion and attrition which result from changes in the polymer content may attribute to this effect. Over the years, the use of polymers and other materials to prolong the drug release has become more popular. The use of polymers combinations is an approach that may allow formulators to develop sustained release drug dosage forms that may show performance improvements over the individual polymer components. 10 and 30\% w/w of HPC was used to study the effect of starch and lactose as diluents on drug release, since higher HPC levels may mask the differences impacted by the diluents on drug release. The equal concentrations of starch and lactose are used as released modifiers. Since low concentration of HPC did not show any considerable effect in the extended release rate (data not shown), therefore, the changes of release rate were mainly influenced by the changes of diluents. At the presence of diluents increased, the release rate also increased. Fig. 2 confirmed that while caffeine release of B-7 (10\% diluents) was only $68 \%$, when the diluents were increased in B-5 (22\% diluents) the percent release of caffeine increased to 76\%. Similarly, B-8 provided higher release (97\%) compared to B-6 at 90\%. In this experiment, MCC was used in low amounts ( 2.2 and 5 $\%)$ regarding to the compression issue. Thus, mixing lactose and starch in a ratio of 1:1 appeared to control the drug release of hydrophilic matrices. In general, native starch is insoluble in water. However, starch swells in contact with water; therefore it has some disintegrating properties (21). The presence of starch in the HPC matrix tablet could modify the release rate which is based on its fast water uptake followed by the HPC swelling. Lactose is water soluble and the use of lactose in the mixture of diluents affected the release kinetics, by reducing the tortuosity (twisting) of the diffusion pattern of the drug.

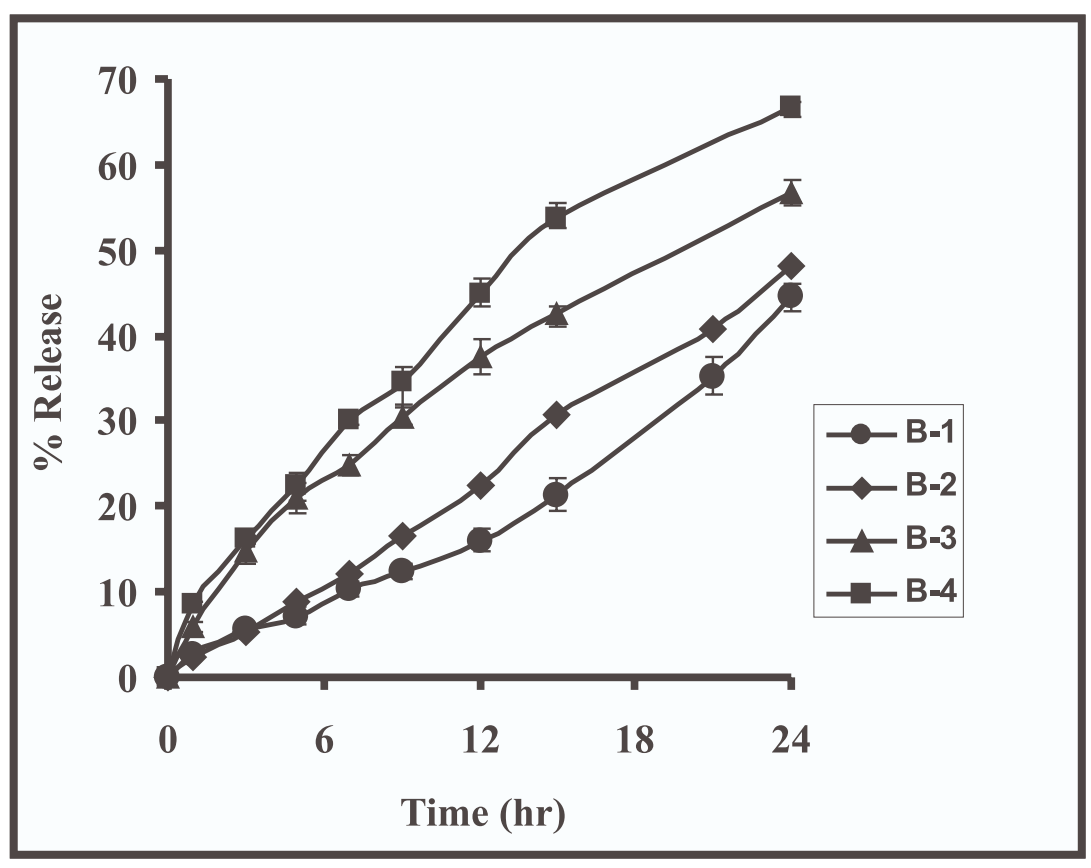

GRAFIC 1 - Percent release of caffeine from HPC matrix tablets, containing various levels of polymers. The caffeine loading of $582 \mathrm{mg}$ was kept constant in the tablets of these batches 


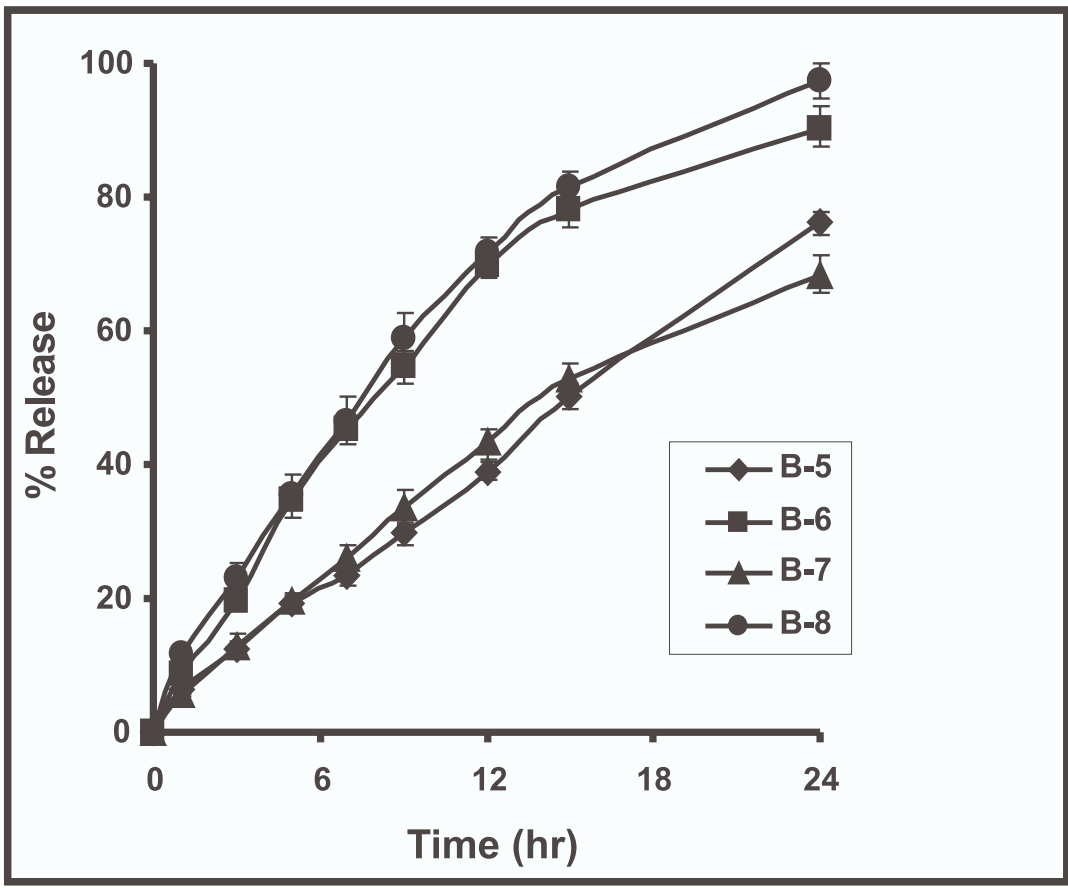

\section{GRAFIC 2 - The effect of diluents of corn starch, lactose and MCC on hydrophilic tablet matrix}

Drug release kinetic is often to describe the drug release behavior from polymeric system. The quantity of drug released from controlled release tablets is often analyzed as a function of the square root of time; this is typical for matrix systems where drug release is governed by pure diffusion. However, the use of this relationship in swellable systems is not completely justified, such as systems can be erodible and the distribution of the relaxation of polymeric chains to drug transport has to be taken into account. Therefore, exponential model was used. The observation on the swelling process showed that significance expansion was formed at time 0 to 5 hours. Then, the swelling increased gradually at 7 to 18 hours. In the last 6 hours, the erosion process is higher than the swelling process. As observed from Table 2, the mechanism of release was found to be anomalous. This is mainly due to the fact that all the $n$ values varied from 0.7317 to 0.8575 with squared correlation coefficient $\left(\mathrm{R}^{2}\right)$ in the range of $0.9904-0.9967$, for at least $50-60 \%$ of drug released.

\section{TABLE 2 - Kinetic parameters from the caffeine matrix tablet}

\begin{tabular}{ccccc}
\hline & B-5 & B-6 & B-7 & B-8 \\
\hline $\mathrm{n}$ & 0.7536 & 0.8575 & 0.8186 & 0.7317 \\
$\mathrm{R}^{2}$ & 0.9904 & 0.9954 & 0.9967 & 0.9931 \\
\hline
\end{tabular}

\section{Conclusion}

Caffeine controlled release matrices were prepared successfully utilizing HPC-HXF and the presence of starch and lactose as diluents. The rate of release can be controlled using the suitable diluents and the right composition. The presence of starch in HPC matrices may bring different effects resulting from interactions between HPC and starch that can affect the properties of the of the gel layer around the tablet, and the presence of lactose as release modifier may result in faster release due to its capability in reduction the tortuosity (twisting) or gel strength of the polymer. The study also showed that the release of drug refers to anomalous mechanism. 


\section{References}

1. Bechgaard H, Ladefoged K. Distribution of pellets in the gastrointestinal tract. The influence of transit time exerted by the density or diameter of pellets. J Pharm Pharmcol. 1978; 30:690-692.

2. Welling PG. Oral controlled drug administration. Pharmacokinetics considerations. Drug Dev Ind Pharm. 1983; 9:1185-1225.

3. Huang X, Brazel CS. On the importance and mechanisms of burst release in matrixcontrolled drug delivery systems. J of Cont Rel. 2001; 73:121-136.

4. Brazel CS, Peppas NA. Temperature and $\mathrm{pH}$ sensitive hydrogels for controlled release of antithrombotic agents. Mater Res Soc Symp Proc. 1994; 331:211-216.

5. Lapidus H, Lordi NG. Drug release from compressed hydrophilic matrices. J Pharm Sci. 1968; 57(8):1292-1301.

6. Sumathi S, Ray AR. Release behaviour of drugs from tamarind seed polysaccharide tablets. J Pharm Pharmaceut Sci. 2002; 5:12-18.

7. Ford JL, Ribinstein MH, McCaul F, Hogan JE, Edgar PJ. Importance of drug type, tablet shape and added diluents on drug release kinetics from hydroxypropyl methyl cellulose matrix tablet. Int J Pharm. 1987; 40:223-234.

8. Machida Y, Nagai T. Directly compressed tablets containing hydroxypropyl cellulose in addition to starch or lactose. Chem Pharm Bull. 1974; 22:2346-2351.

9. Skinner GW, Harcum WW, Barnum PE, Guo $\mathrm{JH}$. The evaluation of fine particle hydroxypropylcellulose as a roller compaction binder in pharmaceutical applications. Drug Dev Ind Pharm. 1999; 25:1121-1128.

10. Willis RC. Starch Analysis. Today's Chemist at Work, Americ Chem Soc. 2004; p. 10.

11. Seppo P, Suihko E, Vidgren M, Paronen P, Ketolainen J. Starch acetate as a tablet matrix for sustained drug release. J Contr Rel. 2004; 94:293-302.
12. Jivraj M, Martini LG, Thompson CM. An overview of the different excipients useful for the direct compression of tablets. PSTT. 2000; 3(2):58-63.

13. Bonati M, Latini R, Tognoni G, Young JF, Garattini S. Interspecies comparison of in vivo caffeine pharmacokinetics in man, rabbit, rat and mouse. Drug Metab Rev. 1984-5; 15:13551383.

14. Arnaud MJ. The pharmacology of caffeine. Prog Drug Res. 1987; 31:273-313.

15. Marks V, Kelly JF. Absorption of caffeine from tea, coffee and coca cola. Lancet. 1973; 1:827.

16. Parikh, D.M. Theory of Granulation, In Handbook of Pharmaceutical Granulation Technology. New York: Marcel Dekker Inc.; 1997.

17. Ritger PL, Peppas NA. A simple equation for description of solute release. II Fickian and anomalous release from swellable devices. J Contr Rel. 1987; 5:37:42.

18. Peppas NA, Bures P, Leobandung W, Ichikawa H. Hydrogels in pharmaceutical formulations. Eur J Pharma Biopharm. 2000; 50:27-46.

19. Peppas NA, Mikos AG. Preparation methods and structure of hydrogels. v. 1. In: Peppas NA, Mikos AG Hydrogels in medicine and pharmacy., NA Peppas ed. CRC Press, Boca Raton, FL.; 1986. p. 1-27.

20. Brannon-Peppas L. Preparation and characterization of crosslinked hydrophilic networks. In: Brannon-Peppas L, Harland RS. Absorbent polymer technology. Amsterdam: Elseveir; 1990. p. 45-66.

21. Pohja S, Suihko E, Vidgren M, Paronen P, Ketolainen J. Starch acetate as a tablet matrix for sustained drug release. J Contr Rel. 2004; 94:293-302.

Recebido em/Received in: February 15, 2006. Aprovado em/Accepted in: April 13, 2006. 